\section{Reuniões sem fim}

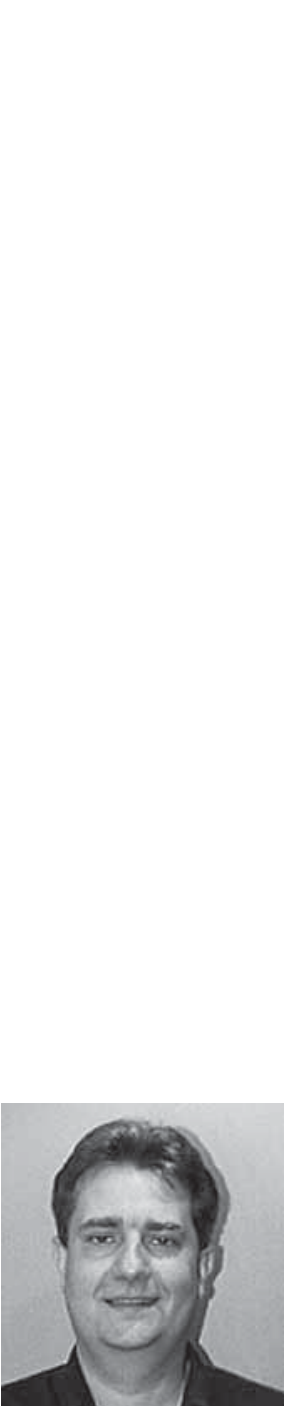

Antonio Gelis Filho

FGVEAESP magine a cena: duas ou mais pessoas se encontram no corredor da organização. Algum tema é levantado, em geral algo que gera ansiedade entre os executivos. Após uma série de verbal izações recheadas de emoção e por vezes de bravatas, alguém propõe a "solução": precisamos agendar uma reunião para tratar desse assunto.

U ma vez agendada a reunião, épreciso quórum, então outros executivos serão convocados para discutir o "problema". A reunião é realizada com apenas parte dos convidados e, muitas vezes, apenas uma decisão é tomada, a de agendar uma série de novas reuniões sobre o mesmo assunto. Ao final de todo o processo, há no ar uma sensação de frustração euma percepção de que "nada foi resolvido". Seriam as reuniões intrinsecamente inúteis ou apenas uma ferramenta organizacional muito mal utilizada?

Evidências da prática organizacional e de pesquisas em administração apontam para a segunda hipótese. 0 problema não está na realização de muitas reuniões, mas sim em sua realização por motivos inadequados. Assim, é preciso evitar o "reflexo da convocação de reuniões", uma espécie de tendência dos seres humanos de se agregarem quando uma situação geradora de tensão surge. Embora essa reação possa parecer natural, ela é contraproducente e, ao final, paradoxalmente poderá gerar ainda mais tensão.
Como agir? Em primeiro lugar, é preciso que a cultura de convocação de reuniões seja combatida. Um gestor deve ser responsável pela eficácia das reuniões que convoca. Além disso, por vezes basta a formulação da pergunta "qual o produto que espero dessa reunião?" para que seja evitada uma reunião desnecessária, pois percebe-se não haver produto que possa ser esperado. E, caso efetivamente haja um produto associado a essa reunião, poderia ser obtido por meio do uso de outra ferramenta, como e-mail ou comunicação eletrônica instantânea?

O controle do número e da duração das reuniões, bem como do número de horasreunião dos executivos e demais colaboradores de uma organização, também pode trazer informações relevantes. Por exemplo, pode ser evidenciado que determinado grupo ou departamento consegue resultados bons com um número bem menor de reuniões que os demais, servindo de "benchmark" para os outros.

Organizações são fenômenos humanos coletivos, portanto sempre estarão associadas a um grande número de reuniões e de outras atividades em grupo. Manter esse número sob controle, por um lado evitando o desperdício de tempo e, por outro, aproveitando seus muitos aspectos positivos, é uma habilidade organizacional essencial. A chave tal vez esteja na capacidade de utilizar as reuniões sempre como ferramenta para obtenção de soluções, e nunca como substituto delas. 